\title{
The Concept of A Religious Humanis Values Education
}

\author{
Hamam Burhanuddin \\ S3 UIN Walisongo, Prodi Studi Islam Konsentrasi Psikologi Pendidikan Islam \\ E-mail: hmmudin@gmail.com
}

\begin{abstract}
Humanist Values Education. Islam never experienced a heyday into the study of various disciplines, this is evident by the presence of muslim scientists. But with the passage of time that Islamic intelektualisme begin to Dim along with the understanding and the culture of taqlid. Whereas the Qur'an gave instructions in order to examine all the scientific disciplines, it can be seen from the verses of the Qur'an which was ordered to examine the nature and seisinya. Religious Humanist Values education which leads to the study of the komprehenshif of good science is both religious and General Education Development Concept is as Islam that humanizing of man in accordance with the duties of man as abdullah and the Caliph in the face of the Earth.
\end{abstract}

Keywords: Islamic Education, Religious Humanist Values,

\section{Introduction}

The strategic role of education as the means of human resources (human development) and human investment. This means that, in addition to educational aims growing hibiscus a better life, has become a cornerstone of coloring and moral and ethics in the process of empowerment of the nation identity. ${ }^{1}$ Departed from the significance of education, then education is the very essence of the process of humanization. ${ }^{2}$ According to Malik Fajar humanization process implies an educational institution with the orientation of the development of the humanitarian aspects of human beings, i.e. physical-biological aspects and spiritual-psychological. Spiritual-psychological aspect of this is that a try adult and insan kamil through education as a positive pretension elements in the construction of the civilized life. ${ }^{3}$ From this idea, then education is the conscious actions with the aim of maintaining and develop nature and potential of the human (resources) towards the formation of the whole person (insan kamil). ${ }^{4}$

\footnotetext{
${ }^{1}$ Karnadi Hasan “Konsep Pendidikan Jawa”, dalam Jurnal Dinamika Islam dan Budaya Jawa, No 3 tahun 2000, Pusat Pengkajian Islam Strategis, IAIN Walisongo Semarang, 2000, p. 29.

2 Paulo Freire in Pendidikan: Kegelisahan Sepanjang Zaman (Pilihan Artikel Basis), Sindhunata (editor), Kanisius, 2001 as in quotation Resensi Amanat, Edisi 84/Februari 2001 p. 16.

${ }^{3}$ Malik Fadjar in Imam Tholkah, Membuka Jendela Pendidikan,Jakarta : Raja Grafindo Persada, 2004, p. v

${ }^{4}$ Achmadi, Islam Paradigma Ilmu Pendidikan, Yogyakarta : Aditya Media, 1992, p. 16
} 
Normative basis, Islam has provided a strong foundation for the implementation of the right to education. First, Islam emphasizes that education was a religious obligation in which the learning process and the transmission of Science is very meaningful for human life. Here's the background down the first revelation to the command of reading, writing, and teaching. (QS. Al-' Alaq: 1-5). Secondly, a whole series of educational implementation is worship to God Almighty (QS. Al-Hajj: 54). As a worship, then education is the duty of the individual to the collective, while the third, Islam provides a high degree of well-educated, scholar or scientist (QS. Al-Mujadalah al Nahl: 11:43). Fourth, Islam provides the foundation that education is a lifelong activity. (Long life education). Fifth, the construction of education according to Islam are dialogist, innovative and open to accepting the good science from both East and West.

Awareness of the importance of education with the conceptual foundation of normative-this is what causes the corpus of Islamic intellectual heritage since the time of the Prophet until the medieval glory. ${ }^{5}$ According to the great achievements of civilization Fazlurrahman, Islam was then a success sustained develop reasoning. ${ }^{6}$

In this phase, originally Islam really has become the inspiration for the transmission of scientific knowledge among Muslims in the form of empirical work to the development of Islamic civilization, so that the normative basis of Islam really be theology Liberation (liberating) and ummah (civilizing). The emergence of a variety of international institutions and the number of scientists who are not only proficient in the field of theology but also tough in science and technology is the proof of the greatness that is written Muslims in this era. ${ }^{7}$

\footnotetext{
${ }^{5}$ As an expression of Mas'ud to describe the condition of the triumph of Islam which allegedly took place between 7-11 M with the figure of Muhammad as modelling is able to change characteristics of the jahiliyyah ' Arab 'towards a community that. Abdurrahman Mas'ud, Menggagas Pendidikan Nondikotomik, Yogyakarta: Gama Media, 2002, p. 65. Fazlurrahman indicates that the characteristics of the Arab Islamic community is a pre-condition for the development of Islam as a means of providing Arab expansion activities that astonishes and means the occurrence of revolutionary change. Toshihiko Izutsu, Relasi Tuhan dan Manusia, pendekatan Semantik terhadap al Qur'an, Yogyakarta : Tiara Wacana, 1997 dan Konsep-konsep Etika Religius, Yogyakarta:Tiara Wacana, 1993.hal. 43.

${ }_{7}^{6}$ Fazlurrahman, Islam, Chicago : Chicago University Press, 1979, p. 1-2.

${ }^{7}$ In susceptible 7-11 Century ad, Islam's glory so that it became the Qibla of the Western world, especially Europe and Spain. It is characterized by the emergence of Islamic thinkers' multi discipline. In addition to the four madhhab as theologian, appear the names of Al Tabari (923) expert original interpretation of the Qur'an. The field of unity and Nietzsche, we know Hasan al-Basri (w 728) and the Ash'ari (d. 935). Also emerging scientists in the fields of science and philosophy of
} 
Great achievements of Islamic era this is what makes people like Mehdi Nakosteen, in the 'History of Islamic origins of Western Education, Philip K. Hitti in The Arabic: a. Short History and Montgomery Watt in The Influence of The Islam and Islamic Spain claimed that in Medieval Islamic civilization has contributed to significant gains in the education field to the Western world. ${ }^{8}$

However spectacular the past Islamic Construction in the further development is not able to be maintained. This phase is increasingly apparent as the year 1258 M, Hulago Khan of Mongolia destroyed Baghdad and Granada as a center of Islamic culture and Civilization that continues on the Western imperialism over Islamic countries. ${ }^{9}$ Scrimmage with the West is not the only factor in the causes of the decline makes people stutter in the face of the development of the science and technology that has been switch to the West, but there is a more serious factor from internal Muslims, such as degradation of moral, pragmatic, hedonist, and secular. ${ }^{10}$

The above problem is still rampant compounded with system dichotomy and the rise of taqlid tradition among Muslims. According to Mas'ud until today there is a general impression that Islamic learning is identical with rigid, stagnates and setbacks. Charge indicators will are the majority of Muslims live in third world countries that economic backwardness and all-round education. This condition is aggravated by way of thinking dichotomies paced as Islam versus non-Muslim, East

biology, mathematics, such as chemical, medicine. They are the true philosophers al Kindi (800-870), (870-950) al farabi, Avicenna (980-1033 M), Averroes, al-Jahiz (d. 255 H) expert on Arabic literature, Al Mas'udi (born 280 H/893 M) experts of philosophy and geography. Al Razi (303H/925 M) Physics, mathematics, astronomy, logic, linguistic, and chemistry. Medicine. The works of al Razi is becoming the source of patent medicine of the West until the 18th century, al Khwārizmī an expert on mathematics. We also know Ibn Haitam, an expert of light. Ibn Hazm, (born 384 H/994 M) historian. Back again, there is al Mawardi (d. 1058) expert in political theory with most of his famous, al ahkam al shulthaniyah. Big name al Ghazali (d. $1111 \mathrm{M}$ ) which is known to the West as the second most important person in Islam after Muhammad, experts, it started to fiqh, kalam and Sufism, philosophy and many more other multi other science thinkers.

${ }^{8}$ Mehdi Nakosteen, History of Islamic Origin of Western Education, Colorado, 1964, Hal. 61-62. look, Faisal Ismail, Masa Depan Pendidikan Islam, Jakarta : Bakti Aksara Persada, 2003, p. 15-16.

${ }^{9}$ Zuhairini, Sejarah Pendidikan Islam, Jakarta : Bumi Aksara, p. 110.

${ }^{10}$ Faisal Ismail mentioned several factors trigger the decline of Islamic civilization, especially in the world of education, first at the end of the reign of the Abbasids in Baghdad and the Umayyad in Cordova (Andalusia/Spain), there was a process of degradation moral values, social and political life in the form of widespread hedonist, materialistic and pragmatic in the life of the Caliph. Second, since the events of destruction Baghdad, Muslims around the world was colonized by Western colonialistimperialist powers. Third, Islam came to spread to different parts of the Islamic world is post-war Baghdad and post Cordova which has lose elanvital, scientific potential and dynamics intellectual. Fourth, the socio-economic conditions has not been encouraging. Read also, Faisal Ismail, the future of Islamic education. 
versus West, science of religion versus science non-religious (Secular Sciences) and other form the dichotomy. These paradigms influenced that of science and technology as a symbol of civilization is growing and growing in the Western world that the non-State. As a result, understanding of the oppressive West over the East and strengthened its dominance has set aside Muslims increasingly backward in the field of science, technology, information, economy and culture (inferior complex). This dichotomy system is not only emerged from the Islamic institution, but it has been plaguing the entire layer. ${ }^{11}$

The illustration above shows there is inaccuracy between texts teaching especially al Quran as normative foundation of the Muslims by the practice of Islamic education in a global era. That is, Islamic education as its mission the establishment of the insan kamil in the modern era can be considered failed in Islamic teachings and universality safely trapped in dehumanizing. In practice, the educational institution is more a process of transfer of knowledge and expertise rather than attempt the formation of consciousness and personality as his mentor protégé through science. In fact, the tendency of education that simply transfer of knowledge and expertise and ignore development of morality is the main feature of the dehumanization of education. ${ }^{12}$

From the thought above, this study is expected to explore the universality of Islamic teachings in the Koran religious humanist Quran about value and its implications for the education of Islam as a framework concept.

\section{Discussion}

\section{A. Definition of Value}

A value derived from Latin Valere or language of ancient France valoir which means price, but when the word is perceived in a certain point of view will have a diverse interpretation there is a value or price according to

\footnotetext{
${ }^{11}$ Abdurrahman Mas'ud, Menggagas Pendidikan Nondikotomik, ......p. 66.

${ }^{12}$ The educational process intended to be limited to the transfer of knowledge (transfer of knowledge). While the humanization is a process of community empowerment through knowledge. Read Paulo Freire, Politik Pendidikan: Kebudayaan, Kekuasaan dan Pembebasan, terj. Agung Prihantoro dan Fuad Arif Fudiyartanto, Yogykarta : Pustaka Pelajar \& READ, 2002, p. 190-1.
} 
economics, Psychology, sociology, politics or religion. ${ }^{13}$ According to Allport (Mulyana: 2004) value is a belief that makes a person act on the basis of her choice while Kupperman interprets the value as a normative benchmark that affects humans in determining the choice between the ways of alternative actions. It gives emphasis on the norm as the external factors that affect human behavior. As a sociologist, ${ }^{14}$ Kupperman looked norm as one of the most important part of social life. Therefore, one of the most important part in the process of value judgment is the involvement of normative values that apply in the community. ${ }^{15}$

Kluckhohn (Brameld, 1957) lays out the value as a conception (implied or expressed, that nature differentiates individual or group characteristics) of what is desirable, which influence the choice between destinations on the way, and the ultimate purpose of the action. ${ }^{16}$ According to the Kulchohn view, Brameld has many implications towards the definition of culture values and something that is seen to be worth when perceived as something desirable. Food, money, home, has value because it has a perception as something good and a desire to acquire it have influenced the attitudes and behavior of a person. But not only the material has value, the idea and the concept can also be a value, such as: honesty, truth and justice. For example, honesty would be a value for someone when he has a commitment to that value which is reflected in the

\footnotetext{
${ }^{13}$ Qiqi Yuliati Zakiyah A. Rusdiana, Pendidikan Nilai, Kajian Teori dan Praktik di Sekolah. Bandung, CV Pustaka Setia, 2014, p 62.

${ }^{14}$ Defines the value of a sociologist as a desire, a need, and the pleasure of someone up on sanctions and pressure from society. While the psychologist will interpret the value as a behavioral tendency originating from psychological symptoms, such as cravings, motives, attitudes, needs and beliefs that are individually owned up on stage was a form of behavior unique. Meanwhile, an anthropologist looking at as the "price" that is attached to the cultural pattern of the society such as in language, customs, beliefs, laws and forms of social organization developed human. Mulyana, Rohmat, Mengartikulasikan Pendidikan Nilai (Bandung: Alfabeta, 2011), p. 9.

${ }^{15}$ Mulyana, Rohmat, Mengartikulasikan Pendidikan Nilai .........p. 9.

${ }^{16}$ According to Scheler's value in reality there are higher and there is also lower if compared to the other. Therefore, according to Scheler values have a hierarchy that can be grouped into four levels of enjoyment Value. On this level there is a series of delightful rating or vice versa which then people feel happy or miserable. The value of life. On this level there are values that are important for life, such as health, public welfare bodies, freshness and others. The value of psychological abuse. On this level there is a psychological value in no way depends on the physical circumstances or environment. The values of this kind is the beauty, truth and knowledge is achieved through pure philosophy. Mulyana, Rohmat, Mengartikulasikan Pendidikan Nilai...., 38. Spiritual Values. On this level there is a sacred value or not. These values are primarily born of the Godhead as the highest value
} 
pattern of thought, behavior, and attitude. Meanwhile, according to Amin Gratitude value is a device of conviction or feeling which is believed to be an identity that gives a special livery on patterns of thought, feeling, behavior or attachment. ${ }^{17}$

From some of the above description is a reference value and belief in choice. Although specific traits such as norms, beliefs, the way, the purpose, the nature and the characteristics of the value is not expressed explicitly. As an example of the idea and the concept can also be a value, such as: honesty, truth and justice. For example, honesty would be a value for someone when he has a commitment to that value which is reflected in the pattern of thought, behavior, and attitude. Values education is teaching or tutoring to students in order to realize the value of truth, goodness and beauty through the process of consideration of the proper values and conditioning a consistent Act, education value here intended to represent all concepts and action education put great attention to the development of humanistic or theistic values.

\section{B. Humanism in West}

Humanist etymology basis is derived from the Latin humanus ${ }^{18}$ and has root homo meaning human. Humanus means human or in accordance with human nature. Whereas in terminology, the humanism means the dignity and worth of every human being, and all efforts to enhance the capabilities of its (physical nonphysical) in full. ${ }^{19}$ Other terms disclosed by Cohen (2007) in David t. Stern.

"Humanism is the passion that animates the authentic professionalism. Humanism is a way of being. It comprises a set of deep-seated personal convictions about one's obligations to others, especially others in need. Humanistic physicians are intuitively

\footnotetext{
${ }^{17}$ Amin Syukur, Studi Akhlak, (Semarang, Walisongo Press, 2010). p. 125.

${ }^{18}$ John Echols \& Hasan Shadily, Contemporary English Grammar, New Delhi, Book Palace, 1998, 362. According to Pius A Partanto and Dahlan Al-Barry mentioned that Human means about humans, human way, while his own humanist means a human, adherents of the teachings of humanism. While humanism itself is a doctrine that emphasizes the importance of humanity and the ideal of humanism in an age of Renaissance based upon ancient Greece civilization whereas modern humanism puts man exclusively. A Partanto, Pius dan M. Dahlan Al-Barry, Kamus Ilmiah Populer.(Surabaya, Airloka : 1994), p. 49.

${ }^{19}$ Mangunhardjana, Isme-Isme Dari A-Z. A., (Yogyakarta: Kanisius, 1997), p. 93.
} 
and strongly motivated to adhere to the traditional virtues and expectations of their calling. Professionalism and humanism are being considered not us separate attributes of a good doctor, but rather the US being intimately linked... ${ }^{20}$

Definition of humanist expressed by Corliss Lamont in his book Philosophy of Humanism, he says;

Humanism is the viewpoint that people have but one life to lead and should make the most of it in terms of creative work and happiness; that human happiness is its own justification and requires no sanction or support from supernatural sources; that in any case the supernatural, usually conceived of in the form of heavenly gods or heavens, immortal does not exist; and that human beings, using their own intelligence and cooperating liberally with one another, can build an enduring citadel of peace and beauty upon this earth. ${ }^{21}$

Corliss Lamont's opinion above is the sum total of the nature of reality, that matter is energy-and not of the mind that is the material that formed the universe, and that supernatural entities is absolutely no. Supernatural unreality at human level means that humans do not have a supernatural and eternal soul; and at the level of the universe as a whole that the Cosmos we don't have a supernatural and Eternal God.

The concept of humanism that leveled by Lamont synonymous with atheism, and this fact freely acknowledged by the humanist. There are two important manifesto that was published by the humanist in a century ago. First published in 1933, and was signed by the most important people of the time. Forty years later, in 1973, the second humanist manifesto published, confirms the first, but contains some additional related developments happening in the meantime. Thousands of thinkers, scientists, writers and media practitioners to sign the second manifesto, backed by the American Humanist Association is still very active. If we learn that manifesto - manifesto, we find a basic foundation on each; atheist dogma that the universe and human beings are not created but there are freely, that humans are not responsible to any other authority other than itself, and that belief in God hinders the development of personal and community.

${ }^{20}$ David T. Stern, et al., "Teaching Humanism, Perspective in Biology and Madicine,.", p. 496.

${ }^{21}$ Corliss Lamont, The Philosophy of Humanism, (Washington, DC: Humanist Press, Half-Moon Fdn, 2001), p. 15. 
Six of the first Humanist Manifesto article is; First; Humanist looks at the universe exists by itself and not created. Second; Humanism believes that man is part of nature and that he appeared as the result of an ongoing process. Third; By holding the organic, humanist view of life found that the traditional dualism of mind and body must be rejected. Fourth; Humanism recognizes that religious and culture of human civilization, as clearly illustrated by anthropology and history, is the product of a gradual progression to interact with the natural environment and social heritage. Individuals who were born in a certain culture is largely shaped by the culture. Fifth; Humanism asserts that the nature of the universe is described by modern science or the supernatural cosmic makes any warranty whatsoever for human values is not acceptable. The sixth; we are convinced that the time has passed for theism, deism, modernism, and some kinds of "new thinking". From the definition above, humanism appears once the humanist assumes that humans are the center of all activities by leaving the role of God in his life. This is different from the Islam that believes there are other forces in the human self that is the creator of this nature.

\section{Humanism in Islam}

The concept of the Humanist question in Islam is the humanizing of man corresponds to his role as Khalifa on Earth. Ali Shariati argued that humanism is the expression of a set of values of the divine essence which exists in man which is a hint of religion in culture and moral man, who does not successfully proven the existence of ideology-the ideology of modern due to their challenge against religion. ${ }^{22}$

According to Shariati purpose of education to form the ideal man, the man who has three attributes, or properties of the insan: self-awareness, willingness and creativity. To manifest the human being in terms of actual people (not basyar), then the purpose of education shall be directed to guide humans in developing its own potentialities as intellectual potential and creative potential. In addition the education of human nature toward 1996), p. 119.

${ }^{22}$ Ali Syariati, Humanisme: Antara Islam dan Mazhab Barat, cet. II. Bandung: (Pustaka Hidayah, 
directing his divinity and prevent a human fall in infamy so that he can run the tasks and functions as the Caliph in the Earth.

While Achmadi argues Islamic humanist is a humanist view of humanity, namely teosentris (humanist in Islam), but in the frame of faith to Almighty God (Tawheed). Because it teosentris be a humanist core values (core of value) of the whole system of values in Islam.

Teosentrisme in Islam is "Tauhidi" meaning the whole life centered on God, one God. God as ghayatul hayat (life purpose). The concept of monotheism as the Islamic aqeedah contain doctrinal implications that the purpose of human life is worship to God (QS. Al Dzariyat: 56) and assume the mandate as Caliph of God on Earth (Qur'an al-Baqarah: 30), Yunus: 14, al-An'aam: 65. A further implication of the concept of unity is the basic value of the entire order of values in Islam as norms and guidelines of life, especially the lives of Muslim religiosity. ${ }^{23}$

The Qur'an uses the term to name the four men, the basyar, al-nas, the sons of adam and al-insan. Of the fourth such term has the meaning which varies according to the context referred to in the Qur'an. First, a term repeated in the basyar al-Qurt'an as much as 36 times and 1 with derivation. ${ }^{24}$ The term basyar is used in the Qur'an to explain that man as a biological creature. For example a man as a biological creature is God's word in QS Al-Baqarah, 2:187 that describes the order to retreat when the month of Ramadan and do not sex his wife when during i'tikaf, QS. Ali Imran 3:47 which describes the authority of God who has made Mary had children while no one sex.

Second, the term al-nas repeated in the Qur'an as many as 240 times. ${ }^{25}$ Term al-nas is used in the Qur'an to explain that human beings as social animals. As an example of human beings as social animals is the word of

\footnotetext{
${ }^{23}$ Achmadi, Ideologi Pendidikan Islam. Paradigma Humanis Teosentris. (Yogyakarta, Pustaka Pelajar: 2010), p.21.

${ }^{24}$ Muhammad Fuad Abd al-Baqi, al-Mu`jam al-Mufahras li Alfadzal-Quran, (Beirut : Dar al-Fikr, $1997 \mathrm{M} / 1418 \mathrm{H})$, p. 152-153.

${ }^{25}$ Muhammad Fuad Abd al-Baqi... p. 895-899.
} 
God in surat al-Hujurat, 49:13 which explains that man created male and female, the bowler and the tribes so that the known each other to know.

Third, the term sons of Adam repeated in the Qur'an as much as 7 times. ${ }^{26}$ Bani adam term used in the Quran to show that man as a rational being, for example in the QS. Al-Isra, 17:70. In this verse God describes that will glorify the man and provide infrastructure and facilities both on land and at sea. From this verse we can understand that human potential through his mind to improve the welfare of her life.

Fourth, the term al-insan repeated in the Qur'an as much as 65 times and 24 derivation i.e. insa 18 times and al-nas 6 times. ${ }^{27} \mathrm{Al}$-insan term used in the Qur'an to explain that man as spiritual beings. For example in QS. 51:56 Al-Dzariyat, who explains that humans and Jinn were created by God is nothing but to worship him. QS. Al-Ahzab, 33:72 describes the mandate given by God to man.

From some of the verse above it can be concluded that human beings are perfect. The advantages compared to other human beings from the beginning to the process of its creation (Qur'an al-Sajda, 32:7-9, al-Insan, 76:2-3), shape (QS. al-Tin, 95:4) as well as the tasks that are given to humans as a Caliph in the face of the Earth (Qur'an, al-Baqarah 2:30-34, alAn'aam, 6:165) and as being obliged to serve God (Qur'an, al-Dzariyat, 51:56). So the high degrees of men, in the eyes of Islam, humans must use God given potential to him to develop itself well with sensory, resourceful nor his heart so it's really become a whole person.

\section{The Concept of Religious Humanism Education Value}

According to the reasoning spirit of Sardar Ziaudin intelektualisme Islam of the past has now been replaced with a tradition of following (taqlid). Evidence of this phenomenon is the lack of new discoveries during this century of interdisciplinary science, though many other thinkers that was born, at best works that appear are the work of advanced earlier

\footnotetext{
${ }^{26}$ Muhammad Fuad Abd al-Baqi....p. 32.

${ }^{27}$ Muhammad Fuad Abd al-Baqi....p. 119-120.
} 
figures, nothing really recently. This is compounded with the political map of the world that Western secular berideologi driven through modern institutions that enter into the world of Islam. Because this is what makes internal Abdul Hamid Abu Sulaiman in the journal 'Islamization of Knowledge with special Reference of Political Science ' (1985), commented that the multidimensional crisis experienced by Muslims because it caused some things among others; the decline of the people (the backwardness of the ummah), weakness of the people (the weakness of the ummah), stagnation of thinking people (the intellectual stagnation of the ummah), absence of ijtihad people (the absence of ijtihad in the ummah), the absence of cultural progress of ummah (the absence of cultural progress in the ummah), out of the people of the basic norms of Islamic civilization (the ummah losing touch with the basic norm of Islamic civilization).

According to Ali Ashraf, the educational model with pressure on the transfer of knowledge and expertise than the construction of morality of individualistic attitude will bring up, skeptical, was reluctant to accept the things non-observational and attitudes away from the values of the Ilahiyah nuanced humanity. Due to further this education model, will produce a mechanistic appreciation of humanity that ignores much of the value of cultural, creative and imaginative. It is this fact that caused the wisdom, spiritual intelligence, human consciousness towards the meaning of life, its natural and social environment be failed to grow and will eventually die and create tension free as conflict and war, the crisis of ethical values, dislocation, alienation, emptiness of spiritual values and so on.

To that end, Islamic education should be able to deliver man towards perfection and completeness of human values in a real sense of the human system as a unique, independent and creative as the revelation of the function Qurán as a guidance for mankind and the descriptors for the guidance and the criterion between right and wrong (Q.S./al-Baqarah 2:185).

Al Quran, the Result was instrumental in rectifying the failure of the education system that is stuck in a process of dehumanization. The 
ultimate goal of education in Islam is the process of formation of selflearners (man) to fit with the nature of its existence.

The existence of freedom of motion for each element in the world of education is especially learners to develop themselves and which have potential to the maximum. During the heyday of Islam, education has been able to exercise its role as a container of empowerment of learners, but along with the decline of the Islamic world, the Islamic world ever undertook to decline. Even in any paradigm shift occurs from the paradigm of active-passive-progressive became defensive. As a result, Islamic education undergoes a process of "isolation" and marginal from the environment in which it is located.

From the description above, there are some things that can be used as an effort to re-awaken and puts the world of Islamic education on proper roles i.e. human or humanizing humanization at once reorganized the paradigm Islamic education are active again so-progressive, namely:

First, put back the entire educational activity (talab-al-ilm) at the frame theological work. That is to say, the whole intellectual activities are always grounded by the values of Islam, in which the ultimate goal of these activities is the entire effort to uphold religious and looking for God, as the word ridla Allah SWT; And to those who have been given knowledge, believes that the Qur'an that's what right from your Lord then they believe and submit to their hearts to him and verily God is the giver of Clues for people who believe in a straight way. (QS. Al-Hajj: 54).

Second, the existence of equalization (balancing) between religious disciplines and the development of intellect in the education curriculum. One of the main factors of marginalization in the world of Islamic education is the tendency for further religious studies operates and does not give a balanced portion on the development of the science of nonreligious, even denied the studies of non-religion. Therefore, a balancing between religious and non-material religion in the world of Islamic education is a necessity if it is to the world of Islamic education back to survive in society. Many explaining the Qur'an in verses kauniah in order for 
the human thinking and reviewing of this universe, how elevated sky, Earth, mountains is spread is enforced, a human being was created and so on. This indicates so that Muslims learn a variety of science, not restricted to studying the religious sciences. And the Prophet Muhammad ordered his companions to study into the land of China. This as a basic command of the Prophet so that Muslims learn Science-General Science because China is known at the time as the country that has the expert treatment or physicians.

Third, it should be given freedom to the civitas Academics to perform scientific development to its fullest because during the period of the decline of Islam, created many restrictions and forbidden territory to the debate and dissent that resulted in the narrowness of the intellectual development of the region. If not to eliminate, at least reopen, bulkhead and the territories that had been off-limits for debate, then the region will increasingly broad intellectual development that will certainly open up opportunities for the development of wider scientific knowledge on the World Islamic education in particular and the world of Islam at large.

Fourth, start trying to implement educational strategy grounded. This means that the strategy implemented is adapted to the situation and environmental conditions in which the educational process is implemented. In addition, the materials provided are also adapted to the situation and the existing conditions, at least there is always applicable material and have a relationship with the existing factual reality. With this strategy of Islamic education are expected to be able to produce resources that are truly capable of facing the challenges of the times and sensitive to the environment. Would, one other factor that will really help is the attention and the support of the leaders of the (Government) on the process of extracting and the stirring world of Islamic education. The existence of the attention and support of the Government will be able to speed up the rediscovery of an active Islamic educational paradigm-progressive, which expected the World Islamic education can return capable of running its function as a means of empowerment and humanization. 


\section{Conclusion}

From the explanation above it can be concluded that the Qur'an is concerned about humanism or the humanizing of man, this is proven by the large number of verses of the Qur'an that describe how the human potential of creation, from the start, the his role in the face of this earth and elevated human degrees compared to the creatures of God, but the humanization applied the Qur'an does not leave this earth of mankind's role as servant is required to serve to its creator. As for the humanist Islamic educational paradigms contained in the Qur'an is; First, education is one of the activities aimed at seeking the pleasure of Allah, second, there is a comparison between the religious knowledge and common knowledge, thirdly, freedom in developing science, and a fourth, examines the science the grounded so that it can be implemented in everyday life.

\section{Bibliography}

Achmadi, Ideologi Pendidikan Islam. Paradigma Humanis Teosentris. Yogyakarta, Pustaka Pelajar: 2010. , Islam paradigma Ilmu Pendidikan, Yogyakarta : Aditya Media, 1992.

al-Baqi, Muhammad Fuad Abd, al-Mu`jam al-Mufahras li Alfadzal-Qur`an, Beirut : Dar alFikr, $1997 \mathrm{M} / 1418 \mathrm{H}$.

Fadjar, Malik, dalam Imam Tholkah, Membuka Jendela Pendidikan,Jakarta : Raja Grafindo Persada, 2004.

Fazlurrahman, Islam, Chicago : Chicago University Press, 1979.

Freire, Paulo, dalam Pendidikan: Kegelisahan Sepanjang Zaman (Pilihan Artikel Basis), Sindhunata (editor), Kanisius, 2001 sebagaimana di kutip dalam Resensi Amanat, Edisi 84/Februari 2001.

, Politik Pendidikan: Kebudayaan, Kekuasaan dan Pembebasan, terj. Agung Fudiyartanto, Prihantoro dan Fuad Arif, Yogykarta: Pustaka Pelajar \& READ, 2002.

Hasan, Karnadi, "Konsep Pendidikan Jawa”, dalam Jurnal Dinamika Islam dan Budaya Jawa, No 3 tahun 2000, Pusat Pengkajian Islam Strategis, IAIN Walisongo Semarang, 2000,

Ismail, Faisal, Masa Depan Pendidikan Islam, Jakarta : Bakti Aksara Persada, 2003.

Izutsu, Toshihiko, Relasi Tuhan dan Manusia, pendekatan Semantik terhadap al Qur'an, Yogyakarta: Tiara Wacana, 1997 dan Konsep-konsep Etika Relegius, Yogyakarta:Tiara Wacana, 1993.

Lamont, Corliss, The Philosophy of Humanism, Washington, DC: Humanist Press, HalfMoon Fdn, 2001.

Mangunhardjana, Isme-Isme Dari A-Z. A., (Yogyakarta: Kanisius, 1997).

Mas'ud, Abdurrahman, Menggagas Pendidikan Nondikotomik, Yogyakarta : Gama Media, 2002. 
Nakosteen, Mehdi, History of Islamic Origin of Western Education, Colorado, 1964.

Pius, A Partanto, dan M. Dahlan Al-Barry, Kamus Ilmiah Populer. (Surabaya, Airloka: 1994).

Rohmat, Mulyana, Mengartikulasikan Pendidikan Nilai, Bandung: Alfabeta, 2011.

Rusdiana, Qiqi Yuliati Zakiyah A. Pendidikan Nilai, Kajian Teori dan Praktik di Sekolah. Bandung, CV Pustaka Setia, 2014.

Shadily, John Echols \& Hasan, Contemporary English Grammar, New Delhi, Book Palace, 1998.

Stern, David T. et al., "Teaching Humanism, Perspective in Biology and Madicine,.".

Syariati, Ali, Humanisme: Antara Islam dan Mazhab Barat, cet. II. Bandung: Pustaka Hidayah, 1996.

Syukur, Amin, Studi Akhlak, Semarang, Walisongo Press, 2010.

Zuhairini, Sejarah Pendidikan Islam, Jakarta : Bumi Aksara,1994. 